\title{
estrutura da posse de cativos nos momentos iniciais da cafeicultura no nordeste paulista e no sul de minas \\ gerais (1880-1888) ${ }^{\star}$
}

\section{structure of slaves ownership in the early stages of coffee growing in the northeast of são paulo and in the south of minas gerais} (1880-1888)

\author{
Rafaela Carvalho Pinheiro $\star \star$ \\ Faculdade de Filosofia, Letras e Ciências Humanas, Universidade de São Paulo, São Paulo, São \\ Paulo, Brasil \\ Luciana Suarez Lopes $\star \star \star$ \\ Faculdade de Economia, Administração e Contabilidade, Universidade de São Paulo, Ribeirão \\ Preto, São Paulo, Brasil
}

\section{RESUMO}

A produção significativa de café tanto no nordeste paulista quanto no Sul mineiro já em finais dos Oitocentos dava mostras de grandeza, ganhando espaço em meio à produção de gêneros de subsistência utilizando-se ainda dos braços cativos. O presente trabalho se propõe a realizar um levantamento de aspectos que permitam analisar a estrutura de posse de escravos em seus momentos finais e ao mesmo tempo nos períodos iniciais do café, na vila paulista de Ribeirão Preto e no município mineiro de Campanha, por meio dos inventários post-mortem coletados nas duas localidades (1880-1888).

Palavras-chave: Estrutura da posse. Escravos. Café. Ribeirão Preto. Campanha.

\begin{abstract}
Significant coffee production in the northeast of São Paulo and in the south of Minas Gerais in the late nineteenth century showed signs of greatness, gaining space in the midst of the production of subsistence crops using the captive arms. The present work intends to carry out a survey of aspects that allow to analyze the structure of slave ownership in its final moments and at the same time in the initial periods of the coffee, in the São Paulo village of Ribeirão Preto and Minas Gerais municipality of Campanha, through inventories post-mortem collected in the two localities (1880-1888).
\end{abstract}

Keywords: Structure of ownership. Slaves. Coffee. Ribeirão Preto. Campanha.

* Agradecemos imensamente às contribuições dos pareceristas anônimos da revista e ao Conselho Nacional de Desenvolvimento Científico e Tecnológico (CNPq) pelo financiamento da pesquisa.

Submetido: 27 de novembro de 2017; aceito: 12 de novembro de 2018 .

$\star \star \quad$ Mestre em História Econômica pela Universidade de São Paulo. E-mail: rafaelasrpinheiro@usp.br

$\star \star \star$ Professora de História Econômica do Departamento de Economia da Faculdade de Economia, Administração e Contabilidade da Universidade de São Paulo. E-mail: lslopes@usp.br 


\section{Introdução}

Os atuais municípios de Ribeirão Preto (SP) e Campanha (MG) estão localizados, respectivamente, no nordeste do estado de São Paulo e no Sul de Minas Gerais, distante o primeiro aproximadamente 330 quilômetros da capital paulista e o segundo a 316 quilômetros da capital do estado mineiro. Pouco mais de 370 quilômetros separam as duas localidades. Hoje, essa viagem ainda é longa; em meados do século XIX, certamente não poderia ser feita em horas, mas em vários e longos dias. Mesmo assim, no início dos Oitocentos, diversos habitantes da região Sul de Minas Gerais partiram em direção ao nordeste paulista em busca de melhores oportunidades. Dentre os primeiros habitantes da então Vila de São Sebastião do Ribeirão Preto, encontramos vários oriundos do Sul mineiro e vários vindos de Campanha.

Mapa 1 - Ribeirão Preto (SP) e Campanha (MG)

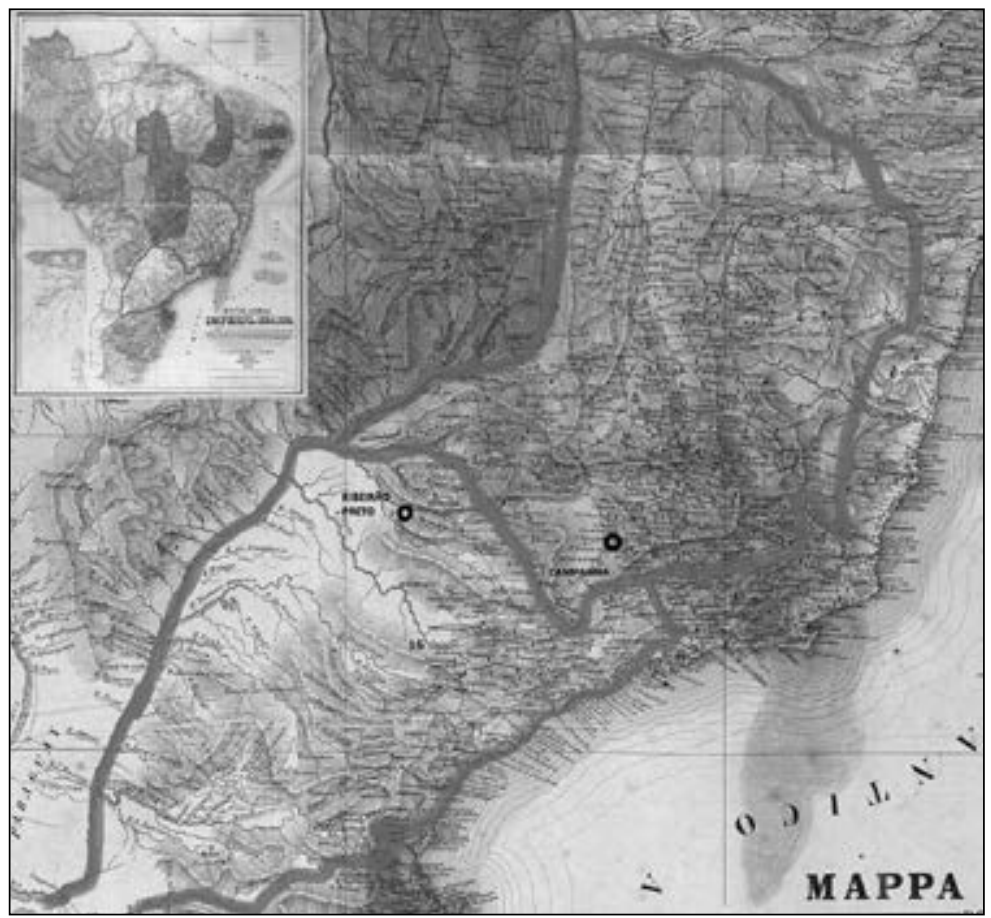

Fonte: Penha (1883). 


\section{Sobre a fonte documental}

Os inventários post-mortem constituem fonte inestimável de informações sobre os bens e costumes das populações passadas. As informações contidas nos processos dão subsídios suficientes para o desenvolvimento de estudos nas áreas de demografia, economia, história e sociologia. É certo que seu grau de detalhamento depende, em boa medida, do período e da região estudados, mas de um modo geral pode-se dizer que os inventários post-mortem permitem uma aproximação com os costumes e as condições de vida das famílias às quais dizem respeito, sendo possível reconstruir toda uma época passada:

À luz que se irradia dessas laudas amarelecidas pelos anos e rendadas pelas traças, vemo-las surgirem vagarosamente do fundo indeciso do passado e fixarem-se nas encostas vermelhas da colina fundamental, as casas primitivas de taipa de mão e de pilão. [...] É o sítio da roça, que aparece [...]; as palhoças de agregados e escravos; os algodoais pintalgados de branco; o verde anêmico dos canaviais, em contraste com o verde robusto e lustroso da mata convizinha. (Alcântara Machado, 1972, p. 21)

Em linhas gerais, as primeiras informações dos processos são os nomes do inventariado e do inventariante, a data e o local de abertura do processo. Em seguida, eram informados os herdeiros e os bens pertencentes ao espólio. Para garantir a veracidade das informações prestadas e impedir que o inventariante deixasse de apresentar propositalmente algum bem, reservando este para si próprio, os demais herdeiros tinham que se mostrar de acordo com as informações prestadas e autorizar o prosseguimento do processo. Eram, então, descritos todos os bens possuídos pelo indivíduo no momento de sua morte e os valores que este, porventura, tivesse a receber ou para pagar a terceiros. Caso todos os herdeiros concordassem com as informações prestadas pelo inventariante e com as avaliações, fazia-se o "Auto de partilha", ou seja, o auto de divisão dos bens. A abertura dos processos era obrigatória para todos aqueles que possuíam bens e/ou filhos menores ${ }^{1}$.

1 Sobre a utilização dos inventários e testamentos como fonte de pesquisa, considerar o texto de Flexor ([1986-2006]). 
Para o estudo ora desenvolvido, foram utilizados 236 inventários, sendo 98 para Ribeirão Preto e 138 para Campanha. Esses correspondem ao total de inventários disponíveis para as duas cidades no período 18801888, incluindo-se aqueles abertos após a Abolição da Escravidão. $\mathrm{Na}$ época da coleta de dados, os processos de Ribeirão Preto estavam localizados no Arquivo do Fórum de Ribeirão Preto; já os de Campanha localizavam-se no Centro de Memória Cultural do Sul de Minas (CEMEC) e no Fórum Municipal da cidade.

\section{Campanha e Ribeirão Preto}

No final do século XIX, as localidades de Campanha e Ribeirão Preto apresentavam graus de desenvolvimento bem distintos. Ribeirão despontava como uma das principais localidades cafeicultoras de São Paulo, sendo sua economia dinâmica e diversificada, e marcantes os seus vínculos com o comércio exterior. Já Campanha tinha sua economia voltada para o mercado interno, e a cafeicultura encontrava-se em seus momentos iniciais. Em 1900, Ribeirão Preto possuía quase 60 mil habitantes, enquanto Campanha contava com pouco mais que $19 \mathrm{mil}^{2}$.

Contudo, dados do "Recenseamento geral do Império" mostram que poucos anos antes a situação era distinta, pelo menos em termos populacionais. Campanha, em 1872, possuía uma população total de 20.771 habitantes, dos quais 6.750 eram escravos. Já Ribeirão Preto, possuía, em 1874, um total de 5.552 habitantes, entre estes 857 escravos. A porcentagem de cativos na população total das duas localidades mostra-se bastante diferente: Campanha possuía 32,5\% de escravos em sua população e Ribeirão Preto, apenas 15,4\%. A julgar pela população e pela mão de obra cativa presentes nas localidades, poderíamos supor ter Campanha mais condições de evoluir economicamente que Ribeirão Preto. Entretanto, não foi isso o que ocorreu.

Campanha, localidade mineira bem mais antiga que a de Ribeirão Preto, tem sua origem ligada ao início da exploração aurífera em Minas Gerais, iniciada pelos bandeirantes paulistas ainda no século XVII. O

2 A população campanhense, com 20.771 habitantes em 1872, diminuiu para 19.120 em 1900. Essa diminuição relaciona-se com os desmembramentos de São Gonçalo do Sapucaí em 1880 e Três Corações do Rio Verde em 1884. 
arraial foi fundado em 1737 por Cipriano José da Rocha, ouvidor-mor da Comarca do rio das Mortes. Em 1739 foi elevada à categoria de paróquia, sendo em 1752 instituído, por ordem régia, o Distrito de Santo Antônio do Vale da Campanha do Rio Verde (IBGE, 2014).

Seu desenvolvimento em termos de crescimento populacional e a necessidade de realização de obras públicas, como calçamento de ruas e abertura de estradas, fizeram com que os residentes de maior influência solicitassem a criação da Vila de Campanha em 1795. A Câmara Municipal de São João del-Rei, sede da comarca, preocupada com as perdas de receita obtidas através de lojas, vendas e criação de gado já abundantes na região, foi contrária à solicitação, alegando ser a população local composta majoritariamente por mulatos, escravos e mestiços, desprovidos de nascimento e conceito, não possuindo as características necessárias para os cargos de juízes e vereadores (Andrade; Cardoso, 2000). Apesar dos protestos, o arraial foi elevado à categoria de vila em 1798, recebendo o nome de Campanha da Princesa da Beira.

Localizada na região mais ao Sul da capitania, Campanha da Princesa, termo da Comarca do rio das Mortes, abarcava dez freguesias, sendo elas Lavras do Funil, Baependi, Pouso Alto, Santa Ana do Sapucaí, Camanducaia, Ouro Fino, Itajubá, Cabo Verde, Jacuí e Aiuruoca. Em 1833, a Comarca do rio das Mortes foi desmembrada, dando origem à Comarca do rio Paraibuna e à do rio Sapucaí, congregando os termos de São Carlos do Jacuí e Pouso Alegre, tendo Campanha como sede da comarca do que hoje é considerado Sul de Minas (cf. Graça Filho, 2002).

O Sul mineiro constituía o caminho das tropas que abasteciam a corte, além de ter se convertido no principal centro de produção e abastecimento do mercado carioca especialmente a partir de 1808. Tal região era composta por propriedades produtoras de gêneros de abastecimento, com a utilização ou não de mão de obra escrava. O que não era consumido nas propriedades era remetido ao Rio de Janeiro (cf. Lenharo, 1993, p. 48).

Nesse contexto, Campanha caracterizou-se como a principal vila do território, pelo menos durante a primeira metade do século XIX. Sendo a localidade mais antiga, ao lado de Aiuruoca e Baependi, a vila destacou-se ainda pela expansão de suas freguesias no âmbito comercial, por seu número de cativos e por se interligar comercialmente às demais regiões do Sudeste. Segundo Marcos Andrade, para o ano de 1824, as freguesias 
que compunham o Sul mineiro, a saber, Conceição do Pouso Alto, Nossa Senhora da Conceição de Aiuruoca, Santa Catarina, São Gonçalo, Maria de Baependi e Santo Antônio da Campanha, apresentavam um total de 47.348 habitantes (cf. Andrade, 2010, p. 4).

Para o ano de 1836, o relatório fiscal da província mostra que Campanha ocupava o sexto lugar em atividade açucareira, com 84 engenhos, bem como a maior quantidade de pequenos comércios, com 471 vendas. Assim, a produção nos engenhos era comercializada tanto nesses estabelecimentos quanto nos caminhos que interligavam as fazendas, os arraiais e as vilas até as províncias carioca e paulista, demonstrando a articulação existente entre os setores produtivo e comercial. No que tange à vida nas fazendas, as unidades escravistas giravam em torno do plantio de cana, produzindo açúcar, aguardente e rapadura, além da criação de animais. Por várias décadas a produção consistiu nos cereais, como arroz, feijão e milho, nos animais suínos e bovinos, e em produtos como açúcar, algodão, fumo, chapéus e tecidos. Tais atividades, embora garantissem o enriquecimento dos proprietários mais abastados da região, representavam pouco na composição da riqueza. Porém, essas atividades eram as grandes responsáveis pelas casas de vivenda, benfeitorias e senzalas (cf. Andrade, 2010; Lenharo, 1993).

Já a localidade paulista de Ribeirão Preto tem sua origem na antiga Freguesia de São Simão. Colonizada por mineiros no início do século XIX, a Freguesia de São Simão foi a primeira a ser criada ao sul do rio Pardo, fundada pelo mineiro Simão da Silva Teixeira, originário de São João del-Rei. Foi ele o doador das terras para formação do patrimônio e construção de uma capela em homenagem a São Simão. Em 1842 a capela tornou-se freguesia, sendo elevada à categoria de vila em 1865.

Dentre seus mais antigos habitantes, encontramos, vindo de Campanha, José Borges da Costa (cf. Lages, 1996, p. 139). Morador da região pelo menos desde o final da década de 1820, Costa era um dos principais proprietários da Fazenda Barra do Retiro. Foi ele também um dos principais doadores de terras para formação do patrimônio eclesiástico de São Sebastião, patrimônio este que deu origem à Vila de Ribeirão Preto. Mas José Borges da Costa não foi o único povoador vindo do Sul de Minas Gerais. Como pode ser observado na Tabela 1, vários foram os entrantes mineiros localizados em São Simão por volta de $1835^{3}$. A

3 Infelizmente, a lista nominativa de 1835 não traz a origem dos habitantes listados, 
grande maioria desses mineiros deixou o Sul de Minas durante a década de 1820. O que teria motivado essa migração? Não sabemos ao certo.

Tabela 1 - Relação de moradores recenseados em São Simão, em 1835, que aparecem em listas nominativas anteriores de Casa Branca

\begin{tabular}{|c|c|c|}
\hline MORADOR & ProcedênCIA & $\begin{array}{l}\text { Primeira APARIÇão NAS LISTAS } \\
\text { NOMINATIVAS DE CASA BRANCA }\end{array}$ \\
\hline Simão da Silva Teixeira & São João del-Rei & 1814 \\
\hline José Borges da Costa & Campanha & 1814 \\
\hline Luis Pires de Camargo & Baependi & 1822 \\
\hline Pedro Angelo Pimenta & Lavras & 1822 \\
\hline Amaro José do Vale (pai) & Ouro Fino & 1825 \\
\hline João Pereira de Barros & Lavras & 1825 \\
\hline João Dias & Lavras & 1825 \\
\hline Antonio Jacinto Nogueira & Baependi & 1825 \\
\hline Custódio José Carlos & Lavras & 1825 \\
\hline Vicente Garcia & Lavras & 1825 \\
\hline José Bento Nogueira & Baependi & 1826 \\
\hline Joaquim José Ferreira & São João del-Rei & 1826 \\
\hline Amaro José do Vale (filho) & Ouro Fino & 1826 \\
\hline João José da Cunha & São João del-Rei & 1826 \\
\hline José Antonio Pereira & Lavras & 1826 \\
\hline Manuel da Cunha & Campanha & 1826 \\
\hline Custódio José do Vale & Lavras & 1827 \\
\hline João Xavier do Vale & Lavras & 1827 \\
\hline João Manuel de Pontes & Caldas & 1827 \\
\hline Pedro Alves de Oliveira & Lavras & 1827 \\
\hline Manuel Joaquim dos Santos & Lavras & 1827 \\
\hline André Alves & Campanha & 1827 \\
\hline Antonio Joaquim da Rocha & Cotia & 1829 \\
\hline Domiciano Manuel de Pontes & Caldas & 1829 \\
\hline Joaquim Félix Pereira & Campanha & 1829 \\
\hline Feliciano Pires & Santana & 1829 \\
\hline José Francisco & Lavras & 1829 \\
\hline Antonio Joaquim de Souza & Baependi & 1829 \\
\hline
\end{tabular}

Fonte: Lages (1996, p. 139-140).

mas José Antônio Lages fez um acompanhamento, partindo dos nomes constantes da mencionada lista, nas listas nominativas anteriores referentes à Vila de Casa Branca, nas quais a origem do morador era informada, dando origem aos dados apresentados na Tabela 1. 
Diferentemente de outras localidades, que consideram como a data de sua fundação aquela correspondente à elevação da localidade à categoria de vila, Ribeirão Preto considera como data de fundação a da demarcação das terras doadas ao patrimônio de São Sebastião, feita em 19 de junho de 1856.

A localidade foi elevada à categoria de freguesia em 1870 e, em 1871, pela Lei n. 67, a freguesia foi elevada à categoria de vila, com a denominação de "Villa da Capela de São Sebastião do Ribeirão Preto" (cf. Miranda, 1971, p. 14), sendo oficialmente desmembrada de São Simão. Com esse desmembramento, a então Vila de São Simão perde mais da metade de seu território. A Câmara Municipal foi criada em 1874 e as primeiras eleições ocorreram em 22 de fevereiro daquele ano. O início das atividades administrativas ocorreu em 13 de julho de 1874. A localidade contava então com quatro ruas, seis travessas e dois largos (cf. Miranda, 1971, p. 14).

As primeiras informações sobre a recém-criada localidade são as do Almanak da Província de São Paulo, publicado em 1873. Contudo, os informes limitam-se às datas de elevação à freguesia e à vila, além dos nomes de algumas autoridades locais. O vigário era Ângelo José Philidory; o subdelegado, Antonio Alves Pereira de Campos; e os suplentes, Luiz Antonio da Cunha Junqueira, Jacintho José de Souza e José Rodrigues de Faria.

No entanto, como as informações do Almanak eram referentes ao ano fiscal de 1871-1872, os dados sobre Ribeirão Preto foram incluídos nas estatísticas referentes a São Simão. Apesar de o desmembramento das duas localidades ter ocorrido oficialmente em 1871, a separação administrativa das duas vilas ocorreu apenas em 1874, ano das primeiras eleições e da criação da Câmara. Conforme a Tabela 2, os fazendeiros simonenses dedicavam-se à criação de gado, porcos e aos cultivos do café e da cana-de-açúcar.

O primeiro levantamento mais completo sobre a população ribeirão-pretana e suas atividades econômicas ocorreu em 1874, como parte do "Recenseamento geral do Império" de $1872^{4}$. Naquele ano, como já

$4 \quad$ Na Província de São Paulo, esse levantamento ocorreu em 1874. Os dados do censo foram gentilmente cedidos por Maria Silvia Bassanezi, pesquisadora do NEPO-UNICAMP (Bassanezi, 1998). 
referido, existiam 5.552 habitantes, dos quais 857 eram escravos. Essa população era composta basicamente por brasileiros brancos, solteiros, católicos e analfabetos.

Tabela 2 - Atividade dos fazendeiros simonenses, 1871-1872

\begin{tabular}{l|c}
\hline \multicolumn{1}{c|}{ AtividAdes } & Número De FAZENDEIros \\
\hline Criadores de gado vacum & 16 \\
\hline Criadores de gado vacum e suíno & 27 \\
\hline Fazendeiros de café & 15 \\
\hline Fazendeiros de cana & 1 \\
\hline
\end{tabular}

Fonte: Luné; Fonseca (1873).

Nesse mesmo ano, a população escrava totalizava 15,5\% do total da população em Ribeirão Preto. À primeira vista, esse número pode parecer pequeno, mas outros municípios, no mesmo ano, apresentavam porcentagem semelhante. NoVale do Paraíba, região em que a cafeicultura absorvia a maioria dos recursos, a porcentagem de cativos na população de Lorena e Cruzeiro era de 14,8\%. Em Paraibuna e São José dos Campos as porcentagens eram, respectivamente, 9,1\% e 9,2\% (Marcondes, 2000, p. 9). Em Guaratinguetá, localidade que, "no decênio de 1870, caminhava vigorosamente para o auge de sua produção cafeeira", a porcentagem de cativos na população era de 20,1\% e, em Silveiras, os cativos eram 17,5\% do total de habitantes (Motta; Marcondes, 2000, p. 269-270).

$\mathrm{O}$ rápido desenvolvimento da cultura cafeeira, principalmente durante as décadas de 1880 e 1890, foi o grande motivador do crescimento populacional observado em Ribeirão Preto, no final do século XIX. Entre 1890 e 1900, a população brasileira cresceu a uma taxa anual de aproximadamente 2,5\%, passando de 14.333 .915 habitantes em 1890 para 17.438.434 em $1900^{5}$. No mesmo período, a população ribeirão-pretana passou de 12.033 habitantes, em 1890, para 100.185, em 1900, num crescimento anual calculado em $30,33 \%{ }^{6}$.

5 Disponível em <http://www.ibge.gov.br/home/estatistica/populacao/censohistorico/1872_1920.shtm\#sub_download>.Acesso em 13/12/2006.

6 Caso mantida a integridade territorial desfeita pelo desmembramento dos municípios de Sertãozinho e Cravinhos, respectivamente em 1896 e 1897. 


\section{A chegada da cafeicultura}

As primeiras lavouras de café no Sul mineiro constam das décadas finais do século XVIII, situadas em Aiuruoca, Jacuí e Baependi, no vale do Sapucaí. Tem-se os tropeiros como as figuras que possivelmente trouxeram o café para a região, já que saíam de Minas Gerais para deixar suas mercadorias no Rio de Janeiro "e iam carregar as cangalhas de suas mulas com mudas e sementes de café, no Medanha, antes de subirem a serra de volta" (Valverde, 1967, p. 39). Podem também ter sido os boiadeiros, uma vez que, segundo Mafalda Zemella, desde 1765 as boiadas faziam o caminho do Sul de Minas até o Rio de Janeiro, passando por vales mineiros onde predominavam a criação de gado, como o rio das Mortes, rioVerde e rio Sapucaí. Independentemente de terem sido tropeiros ou boiadeiros os agentes que trouxeram as primeiras mudas do café para a região Sul de Minas, o fato é que a produção inicial do café era destinada ao consumo próprio, de modo que pouco a pouco foi se ampliando para suprir as necessidades locais (cf. Zemella, 1990).

No entanto, grande parte da literatura acerca do café na região aponta a segunda metade do século XIX como o período de introdução da rubiácea. Maria Lucia Prado Costa indica que a introdução do café se deu na década de 1860 e sua expansão na de 1870 por fazendeiros antigos e prósperos da região de Alfenas e Pouso Alegre, decididos em investir na plantação cafeeira (cf. Costa, 2002). Segundo Ricardo Moreira Rebello, em 1870 já existia 220 mil pés de café na Freguesia de Machado, já exportando para o Rio de Janeiro e São Paulo (cf. Rebello, 2006). Um pouco antes, o memorialista Moacyr Brêtas Soares afirma ser 1840 o ano de introdução do café, oriundo da Zona da Mata, na cidade de Muzambinho, sendo cultivado primeiramente em fazendas com muitos escravos (cf. Soares, 1940).

De qualquer forma, foi apenas no último quartel dos Oitocentos que a planta ganhou expressão entre os fazendeiros da região, ainda que em menor escala do que viria a ter nas décadas iniciais do século XX. A expansão do café no Sul de Minas trouxe consigo profundas mudanças em sua economia especialmente a partir de 1870, apresentando uma nova dinâmica na região. De fato, a estrutura social que imperou no século XIX estava em transformação, e com ela o modo de organização 
dos municípios sul-mineiros.A localidade expandiu seus centros urbanos, conseguindo ainda modernizar algumas cidades.

A partir do terceiro quartel dos Oitocentos, Minas Gerais também passou a construir malhas ferroviárias para garantir o escoamento do produto principalmente para o Porto de Santos em São Paulo e o Porto do Rio de Janeiro. Com a expansão da cultura cafeeira, as formas tradicionais de escoamento do produto, tais como as tropas de muares, por exemplo, passaram a ser insuficientes ${ }^{7}$. Além disso, as ferrovias dinamizavam o comércio, minimizavam as perdas de produtos e reduziam o tempo de transporte.

Nesse contexto de transformações, o município de Campanha continuaria ainda apegado à agricultura tradicional na última década da escravidão. Rebello esclarece ser o café produzido naVila de Campanha desde a década de 1820, sem conseguir atender à demanda do termo (cf. Rebello, 2006). Em 6 de janeiro de 1873, o jornal campanhense Colombo ${ }^{8}$ divulga anúncio de compra e venda da Praça do Mercado da cidade, na qual o café é ofertado em meio a itens como milho, feijão, arroz, toucinho, algodão, rapadura, capados, rezes, queijos, sal, frangos e peixes.

Em 1885, o Almanak Laemmert, na página 370, destacava que na Freguesia de Campanha, além de fábricas de velas de cera, sinos, licores, cerveja, chapéus, telhas, tijolos e cachimbos, havia "criação de gado e porcos, sendo as culturas de cereais e cana as mais usadas, começando ultimamente a desenvolver-se a plantação do café”. A mesma fonte declarou que, na Freguesia das Águas Virtuosas, o café já era muito cultivado, junto ao fumo e à cana, havendo ainda uma pequena indústria

7 Bernardo Saturnino da Veiga declarou que "em geral as vias de comunicação do Sul de Minas limitam-se a trilhos feitos a casco de animal e conservados pelo sol, mas entre os lugares de maior comércio existem algumas léguas de sofrível caminho e veem-se várias pontes adquiridas pela província ou pelas municipalidades. Há, contudo, no Sul de Minas, quatro estradas que, não obstante carecerem de urgentes concertos, mudanças, etc., prestam-se mais comodamente ao livre trânsito dos viajantes, tropas e carros de bois: são as do Passa-Vinte, Picu, Itajubá e Samambaia, nos limites desta com as províncias do Rio e São Paulo" (Veiga, 1874, p. 36).

8 Jornal editado em Campanha. Fundado em 1873 por Francisco Honório Ferreira Brandão, Luís Mendonça e Manuel Oliveira de Andrade, o jornal "pretendia ser um difusor das ideias liberais em Minas Gerais” (Abreu, 2015). Atualmente, alguns de seus exemplares encontram-se disponíveis no Arquivo Público Mineiro - APM. 
de cera.Em Senhor do Bom Jesus do Lambary,“a cultura da cana é a mais usada, plantando-se em menor escala fumo e café [...].A freguesia exporta porcos e cereais, e também alguma cera” (Laemmert, 1885, p. 377).

Quanto a Três Corações do RioVerde,"a cana é a cultura mais usada, cultivando-se também cereais e café. Engordam-se muito gado, criando-se igualmente porcos, tudo destinado à exportação" (Laemmert, 1885, p. 379). Na Freguesia do Espírito Santo da Mutuca, por sua vez, "cultiva-se além de cereais, muito café, cana e fumo” (Laemmert, 1885, p. 381). Por fim, em São Sebastião do Cambuquira, somente a cana era a cultura mais empregada.

Assim, segundo o Almanak de 1885, o café no município de Campanha estava em sua fase inicial, consistindo em uma cultura em meio a várias outras. A partir da Tabela 3, apenas metade das freguesias que compunham o município apresentavam plantação cafeeira de maior vulto, voltadas para o comércio, embora em quantidade muito inferior se comparado a cidades do Oeste Paulista ou da Zona da Mata. As demais freguesias provavelmente destinavam sua produção cafeeira para consumo próprio.

Tabela 3 - Cafeicultura em Campanha, em 1885

\begin{tabular}{l|c|c|c}
\hline \multicolumn{1}{c}{ Freguesias } & FAZendeiros & \multicolumn{1}{c}{ CAfeicultores } & PÉs de CAFÉ \\
\hline Campanha & 68 & - & - \\
\hline Águas Virtuosas & 13 & 6 & 100.000 \\
\hline Senhor do Bom Jesus do Lambary & 15 & 3 & 50.000 \\
\hline Três Corações do Rio Verde & 56 & - & - \\
\hline Espírito Santo da Mutuca & 51 & 11 & 200.000 \\
\hline São Sebastião do Cambuquira & 32 & - & - \\
\hline
\end{tabular}

Fonte: Laemmert (1885).

* Utilizamos o termo "cafeicultores" por ser o que se emprega na bibliografia sobre o tema. Contudo, o Almanak Laemmert faz uso do termo "cafelistas".

Para o desenvolvimento tanto do café quanto das demais atividades agropastoris, era indispensável a mão de obra cativa, cuja distribuição em Campanha evidencia que a maioria desta estava empregada na agricultura. O grande número de escravos estava diretamente relacionado ao poderio econômico da elite agrária no Sul de Minas Gerais. Vale ressaltar, porém, que a expansão do café na região ocorreu a partir da década em que acabou a escravidão no Brasil. 
Na Zona da Mata, cuja inserção do café se deu em meados do século XIX ${ }^{9}$, os fazendeiros enfrentaram sérias dificuldades quando se viram sem braços cativos. Tanto suas estruturas de renda comprometidas com posses escravistas quanto o fato de seus cafezais antigos não alcançarem altos níveis de produtividade, quando da abolição, fizeram com que se estreitassem as rendas dos cafeicultores ao longo do tempo. Como consequência, a baixa produtividade implicava uma concorrência desigual com produções de fronteira, bem como a falta de recursos financeiros impossibilitava a introdução de mão de obra assalariada e as inovações na produção (cf. Saes; Castilho, 2013).

No Sul de Minas, ao contrário, em 1888 a produção cafeeira estava ainda muito aquém da sua capacidade, dado o receio dos fazendeiros em deixar de lado as culturas destinadas ao comércio com as quais estavam familiarizados e que havia muito já rendiam frutos. De fato, as fazendas cafeeiras ainda em formação herdaram pouco da cultura escravista, visto que a expansão do café que teve início na década de 1880 se potencializou, alcançando plena atividade nas décadas iniciais do século XX.

No contexto do nordeste paulista, o desenvolvimento da cultura cafeeira teve início na primeira metade do século XIX. Conforme Taunay, a cidade de Campinas teria sido a porta de entrada do café na região. Partindo de Campinas, o café teria demorado um pouco até penetrar o interior, que ainda era pouco habitado, sendo a escassez populacional o motivo dessa demora (Taunay, 1939, v. 2, p. 332).

Registros de viajantes mostram que os poucos habitantes dessas regiões interioranas se dedicavam ao cultivo de gêneros de subsistência e à criação de gado e pequenos animais. Sobre a Freguesia de Casa Branca, D’Alincourt, tendo percorrido a Província de São Paulo no ano de 1818 , relata que

a gente é bisonha, e desconfiada, o sítio, saudável, e alegre; as águas, boas: um comprido vale coberto de arvoredo semicircunda o lugar e a ele vão dar outros menores igualmente cobertos, cuja variedade forma uma agradável perspectiva. Estes povos colhem algodão, milho, feijão, e algum trigo; plantam cana-de-açúcar; porém o forte de seu negócio consta de gado vacum e capados. (D’Alincourt, 1975, p. 65)

9 A historiografia costuma atribuir 1850 como o início de inserção do café na Zona da Mata mineira (cf. Giroletti, 1980; Lanna, 1988; Lima, 1981; Pires, 1993). 
Saint-Hilaire, que visitou a região em 1817, registrou suas impressões sobre o trecho percorrido entre Franca e Mogi-Mirim. Foram aproximadamente 40 léguas, ou 264 quilômetros, atravessando campos pouco acidentados, com pastagens e algumas flores, cujas atividades não se afastavam muito daquelas apontadas por D'Alincourt. Ainda não havia menção ao café, e a atividade predominante era a criação de gado e outros animais, notadamente suínos.

A produção semovente era comercializada via Minas Gerais, mais especificamente São João del-Rei, ou enviada para as cidades de São Paulo ou do Rio de Janeiro.

Os fazendeiros aproveitam-se das excelentes pastagens que o lugar oferece, dedicando-se à criação de ovelhas e de numeroso gado, não negligenciando também a de porcos. Os mais ricos [donos de fazendas ou de grandes propriedades] enviam as suas crias, por sua própria conta, à capital do Brasil, e os negociantes da Comarca de São João del-Rei vão comprar nas próprias fazendas o gado dos criadores menos prósperos. Um grande número de bois da região é enviado também para São Paulo, onde são usados no trabalho dos engenhos de açúcar.Ali, a má qualidade das pastagens não tarda a fazer com que a maioria morra, o que força os seus proprietários a comprar outros. Alguns anos antes da época de minha viagem, os bois não valiam ali mais do que 3.000 réis; em 1819 os negociantes compravam-nos até por 5.000. (Saint-Hilaire, 1976, p. 92-93)

Os primeiros dados sobre produção de café na região seriam registrados pelo marechal Daniel Pedro Müller, em 1836. Sua compilação, feita com base nas listas nominativas de 1835, mostra que, apesar da existência do café, a economia paulista tinha como atividade principal o cultivo da cana-de-açúcar e a produção de seus derivados. Essas atividades concentravam-se no quadrilátero formado pelas vilas de Sorocaba, Piracicaba, Mogi-Guaçú e Jundiaí. Nessa área, destacava-se a Vila de Campinas, responsável por $28,1 \%$ da produção de açúcar e $15,8 \%$ da produção de aguardente da província em 1836 (cf. Müller, 1978, p. 129, 131).

Nessa época, o território do futuro arraial de São Sebastião do Ribeirão Preto pertencia à Vila de Mogi-Mirim. Como foi mencionado anteriormente, em 1841 ocorreria o desmembramento de Casa Branca, em 1865, o de São Simão e, em 1871, o de Ribeirão Preto. De acordo com os dados apresentados pelo marechal e reproduzidos na Tabela 4, 
na região das vilas de Franca e Mogi-Mirim a economia era caracterizada pela criação de animais e pela produção de gêneros alimentícios. Panorama semelhante ao relatado pelos viajantes dez anos antes. A produção de arroz, milho, fumo e algodão nessas duas localidades era consideravelmente maior do que a de Campinas, assim como as criações de gado bovino, suíno, equino, ovino e muar. Essas duas localidades, Mogi-Mirim e Franca, respondiam por aproximadamente 11\% da produção paulista de gado bovino em 1836.

Tabela 4 - Produção de algumas localidades paulistas, 1836^

\begin{tabular}{l|l|r|r|r}
\hline \multicolumn{1}{c}{ Produtos } & UnidAde & Mogi-Mirim & \multicolumn{1}{c}{ CAMPINAS } & \multicolumn{1}{c}{ FranCA } \\
\hline Café & Arrobas & 610 & 8.081 & 211 \\
\hline Açúcar & Arrobas & 40.520 & 158.447 & 271 \\
\hline Aguardente & Cadanas & 2.312 & 7.399 & 337 \\
\hline Arroz & Alqueires & 8.668 & 3.672 & 2.111 \\
\hline Farinha de mandioca & Alqueires & - & 952 & 3.893 \\
\hline Feijão & Alqueires & 12.558 & 21.015 & - \\
\hline Milho & Alqueires & 354.707 & 96.786 & 138.632 \\
\hline Fumo & Arrobas & 1.850 & 358 & 311 \\
\hline Algodão em rama & Arrobas & 355 & - & - \\
\hline Porcos & Unidades & 14.506 & 3.137 & 5.613 \\
\hline Gado cavalar & Unidades & 1.574 & 221 & 353 \\
\hline Gado muar & Unidades & 477 & 29 & 33 \\
\hline Gado vacum & Unidades & 2.313 & 687 & 1.817 \\
\hline Gado lanígero & Unidades & 316 & 134 & 632 \\
\hline Trigo & Alqueires & 16 & - & - \\
\hline Valor da produção & & $308: 325 \$ 620$ & $308: 089 \$ 580$ & $111: 882 \$ 920$ \\
\hline
\end{tabular}

Fonte: Müller (1978, p. 126).

* Há que se ressaltar uma advertência feita pelo compilador aos dados campineiros. Ao final dos quadros apresentados, encontra-se a seguinte observação:"A Câmara Municipal reconhece inexatidão nas informações que dá, não só quanto ao número das arrobas de café e de açúcar, por isso que alguns fazendeiros por uma desconfiança ou prevenção mal entendida o dão menos; como a respeito das terras das fazendas, cuja maior parte é dada por estimativa visto que não se acharão medidas" (cf. Bassanezi, 1998, p. 394).

A partir daí o café se espalha pelo território paulista. Dados do recenseamento 1854 mostram que a produção da província passou de 590.066 para 3.534.256 arrobas, praticamente sextuplicando a quantidade produzida em 1836. Considerando a produção das localidades de Mogi-Mirim e Casa Branca, a produção da primeira, Mogi-Mirim, alcançou as 80 mil arrobas e a da segunda, Casa Branca, 1.750 arrobas. 
Conforme a Tabela 5, em Mogi-Mirim, eram 66 fazendas produtoras, que empregavam 1.536 trabalhadores, dos quais 174 agregados, 380 colonos e 982 cativos, além de 1.500 animais de transporte. A produção total foi avaliada em 320:000\$000, o que corresponde a $4 \$ 000$ por arroba. Já a cultura cafeeira em Casa Branca apresentava números consideravelmente mais modestos. Havia um total de 6 fazendas, que empregavam 400 cativos e utilizavam 89 animais para transporte. Não foram encontrados colonos nem agregados. As 1.750 arrobas produzidas foram avaliadas em 7:000\$000, 4\$000 por arroba, mesmo valor encontrado para Mogi-Mirim.

Tabela 5 - Produção de algumas localidades paulistas, 1854

\begin{tabular}{l|l|c|c|c}
\hline Produtos & Unidade & \multicolumn{1}{c}{ Mogi-Mirim e Casa BrancA } & \multicolumn{1}{c}{ Campinas } & \multicolumn{1}{c}{ FranCA $\star$} \\
\hline Café & Arrobas & 81.750 & 335.550 & sem informação \\
\hline Açúcar & Arrobas & 229.900 & 62.290 & 8.800 \\
\hline Gado & Unidades & 3.600 & sem informação & 3.300 \\
\hline
\end{tabular}

Fonte:Taunay (1939, v. 3, p. 131-132), Bassanezi (1998).

* A fim de recompor a unidade territorial de 1836, agregamos os dados de Casa Branca, vila desmembrada de Mogi-Mirim em 1841.

$\star \star$ Para recompor a unidade territorial de 1836, deveríamos agregar aqui os dados de Batatais, o que não foi possível porque, segundo notas explicativas do censo, a Vila de Batatais não enviou as informações solicitadas pelo recenseador.

$\mathrm{NaVila}$ de Campinas, eram 177 as fazendas produtoras de café. Estas, em 1854, haviam produzido uma safra de 335.550 arrobas. Essas unidades produtivas empregavam 28 agregados, 198 colonos e nada menos que 6 mil cativos, totalizando 6.226 indivíduos. Com relação ao antigo complexo açucareiro, a produção de açúcar, que em 1836 havia sido de 158.447 arrobas, viu-se reduzida a apenas 62.290 arrobas. O número de unidades produtoras, que em 1836 totalizava 93, caiu pela metade. Em 1854, havia apenas 44 engenhos funcionando.

No entanto, o antigo sertão ainda era marcado pela criação de gado. Em Franca, as 90 fazendas que se dedicavam a essa atividade utilizavam o trabalho de 326 agregados, 939 cativos e produziam 3.300 reses ao ano. A produção de derivados da cana era atividade principal de 20 fazendas, cujas produções somadas alcançaram 8.800 arrobas. Essas fazendas contavam com o trabalho de 40 agregados e 243 cativos, totalizando 283 indivíduos. Em termos de valor, a produção anual de gado 
foi avaliada em 45:200\$000, enquanto a produção de açúcar alcançou menos da metade dessa quantia, 20:000\$000. Infelizmente, o censo não traz informações sobre a existência ou não de fazendas cafeeiras no território francano.

O café não era uma atividade a ser desempenhada em regiões distantes. O principal problema enfrentado pelos produtores que se aventuravam a produzir em regiões isoladas era como escoar lucrativamente a sua produção. Sendo assim, o que sacramentou o avanço do café no planalto paulista foi a chegada da ferrovia. Fundada em 1872, a Companhia Mogiana chegou às localidades do nordeste paulista no início da década de 1880. A partir da chegada da ferrovia, o desenvolvimento da cafeicultura se intensificou, chegando a região a ser, na década final do século XIX, uma das principais produtoras de café do Brasil.

Beneficiada pela formação tardia, a área cafeeira do nordeste paulista foi uma das menos prejudicadas pela lei que libertou os cativos em 1888. Sua produção, que em 1886 era de 2.262 .599 arrobas, passa a ser de 7.852.020 em 1920. Considerando agora, apenas a produção de Ribeirão Preto, ela passa de 235.430 em 1890 para surpreendentes 3.370.443 arrobas em 1901. Nessa época, o número de pés de café em produção alcançava a cifra de 29.384.996. Na safra de 1917-1918, última antes da grande geada, os números eram: 31.394 .365 pés de café que produziam 2.760.000 arrobas, maior do que a produção de toda a zona Mogiana em 1886. A produção da safra seguinte caiu para 1.688.000 arrobas; a de 1919-1920, para 560.000; e a safra anotada pelo censo de 1920 alcançou as 741.080 arrobas, 9,4\% da produção da Mogiana de Milliet (cf. Marcondes, 2002, p. 13). Em 1890 eram 100 as fazendas produtoras de café. Em 1901 esse número subiu para 256, mas o censo de 1920 apontou para a existência de um número menor, 141 (cf. Marcondes, 2002, p. 13).

Na próxima seção veremos como era a estrutura de posse de escravos em Ribeirão Preto e Campanha,justamente nesse contexto de expansão da cafeicultura e abolição do trabalho escravo.

\section{A estrutura da posse de escravos}

A estrutura produtiva que imperou ao longo do século XIX no Sul de Minas Gerais foi notadamente fundamentada na mão de obra escrava, 
de modo que a instituição escravista na região persistiu até os seus últimos dias. Nas duas décadas finais do Império, a região computava quase $21 \%$ do total dos escravos da província, atrás apenas da Zona da Mata. A maioria das cidades do Sul mineiro aumentou sua população escrava de 1873 a 1885, como é o caso de Alfenas, Cabo Verde, Caldas, Campanha, Christina, Itajubá, Jaguary, Passos e São Sebastião do Paraíso. As que diminuíram a quantidade de cativos é provável que tenham sofrido desmembramento de seu território (cf. Castilho, 2009).

Em Campanha, os escravos estavam empregados prioritariamente no campo, cumprindo atividades relativas à criação de animais e ao cultivo de gêneros alimentícios. O café, que na última década da escravidão já iniciara sua expansão pelo Sul de Minas, ainda apresentava fraca produção no município, coexistindo sempre com culturas de maior vulto, como o milho e a cana.

Dos 138 inventários campanhenses entre 1880 e 1888, 86 documentos $(62,3 \%)$ apresentam algum cativo. Desses proprietários, 54 (39,1\%) eram do sexo feminino e 84 (60,9\%), do sexo masculino. Esses homens e mulheres possuíam juntos 630 escravos, sendo que os primeiros concentravam $64,4 \%$ dos cativos, com posse média de 7,5; e as segundas detinham $35,5 \%$ dos escravos, com posse média igual a 4,1. A partir da média de cativos em razão da quantidade de inventários, constata-se que há uma média de 4,57 escravos para cada inventariado; se considerada apenas entre os proprietários, a média tem um salto significativo, aumentando para 7,32, o que confirma o caráter escravista da localidade.

Numa comparação entre proprietários escravistas e não escravistas, Campanha chama a atenção para a diferença entre os montantes dos criadores de animais e dos agricultores dada a participação ou não dos escravos. Assim, 69,6\% dos criadores de animais possuíam cativos, detendo $74,1 \%$ da soma relativa à atividade de criação. Quanto aos que cultivavam café, $75 \%$ eram escravistas, com $82,2 \%$ do montante. Os que plantavam as demais culturas também se utilizavam mais do trabalho escravo: $79,2 \%$, importando $60,6 \%$ do valor total ${ }^{10}$.

Como pode ser observado no Gráfico 1, as atividades mais frequentes dos escravistas em Campanha eram a criação e a lavoura. Os tipos de criação eram a de gado bovino, caprino e suíno, além de cavalar e muar.

10 O total de ocorrências não corresponde ao total de inventários, uma vez que havia proprietários que criavam animais e plantavam gêneros alimentícios. 
Tabela 6 - Atividades de criação e cultura dos inventários - Campanha, 1880-1888

\begin{tabular}{l|c|c|c|c|c|c}
\hline \multirow{2}{*}{ AtividAdES } & \multicolumn{2}{c}{ ESCRAVISTAS } & \multicolumn{2}{c}{ NÃO ESCRAVISTAS } & \multicolumn{2}{c}{ TOtAL } \\
\cline { 2 - 7 } & Valor & Ocorrências & Valor & Ocorrências & Valor & Ocorrências \\
\hline Animais & $101: 152 \$ 907$ & 78 & $35: 281 \$ 600$ & 34 & $136: 434 \$ 507$ & 112 \\
\hline Café & $11: 577 \$ 000$ & 9 & $2: 506 \$ 700$ & 3 & $14: 083 \$ 700$ & 12 \\
\hline $\begin{array}{l}\text { Demais } \\
\text { culturas }\end{array}$ & $25: 153 \$ 043$ & 38 & $16: 374 \$ 060$ & 10 & $41: 527 \$ 103$ & 48 \\
\hline Total & $137: 882 \$ 950$ & 125 & $54: 162 \$ 360$ & 47 & $192: 045 \$ 310$ & 172 \\
\hline
\end{tabular}

Fonte: Inventários post-mortem de Campanha (CEMEC e Fórum Municipal).

Gráfico 1 - Principais atividades dos proprietários de cativos - Campanha, 1880-1888

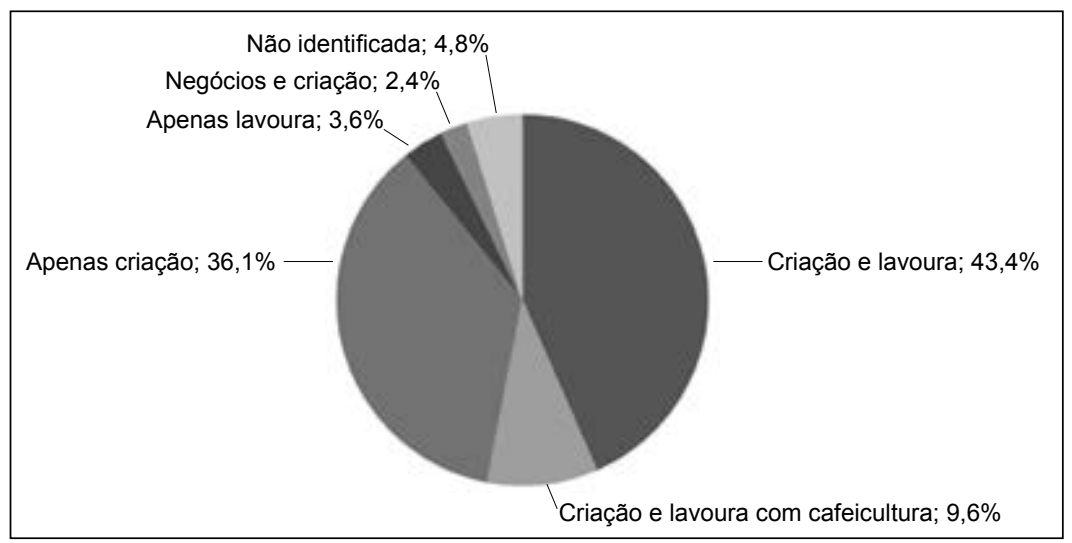

Fonte: Inventários post-mortem de Campanha (CEMEC e Fórum Municipal).

Os gêneros mais cultivados eram o milho e a cana de açúcar, seguidos pelo arroz e pelo feijão, aparecendo também fumo, algodão, banana, mandioca e mamona, embora com pouca frequência. O café era produzido por nove escravistas e três não escravistas ${ }^{11}$.

11 Mais inventários declararam a cultura do café, porém sem menção a valor, tamanho ou quantidade, como é o caso de Maria Cristina Furquim, que em 1881 era dona de 2 mil pés de café, e de Antônio Pinto Caldeira, que em 1881 tinha 300.000 réis em terras e cafezal. Já, nos processos de Elizabeth Máximo Brandão e Castro e Flauzino Borges da Costa, constam apenas que possuíam em 1883 "uma casa com quintal e cafezal" e em 1887 "um canavial no alto do cafezal”, respectivamente. Nesses últimos, é possível que a rubiácea fosse produzida apenas para consumo próprio, não merecendo destaque entre os bens inventariados. 
Não foi possível elencar todas as atividades dos proprietários analisados em relação aos seus negócios ${ }^{12}$, mas os verificados coexistiam com atividades de criação. De fato, os documentos deixam claro que a produção agropastoril se utilizava intensivamente do fator trabalho, já que mais da metade dos proprietários de escravos tanto criavam animais quanto plantavam culturas. Dos proprietários escravistas, apenas quatro não apresentavam criação ou lavoura.

Porém, como evidencia o Gráfico 2, dos 86 processos que constam escravos, apenas $10,7 \%$ dos proprietários eram cafeicultores. No entanto, esses cafeicultores detêm mais que o dobro percentual da riqueza acumulada, $21,4 \%$, e quase o dobro percentual do número de cativos, $20,6 \%$. Sob esse aspecto, de uma maneira geral, os processos fazem crer que o café cumpria papel importante não só no uso intensivo de braços cativos, mas também na acumulação de riquezas ${ }^{13}$.

Gráfico 2 - Participação dos cafeicultores nos inventários de proprietários de escravos Campanha, 1880-1888

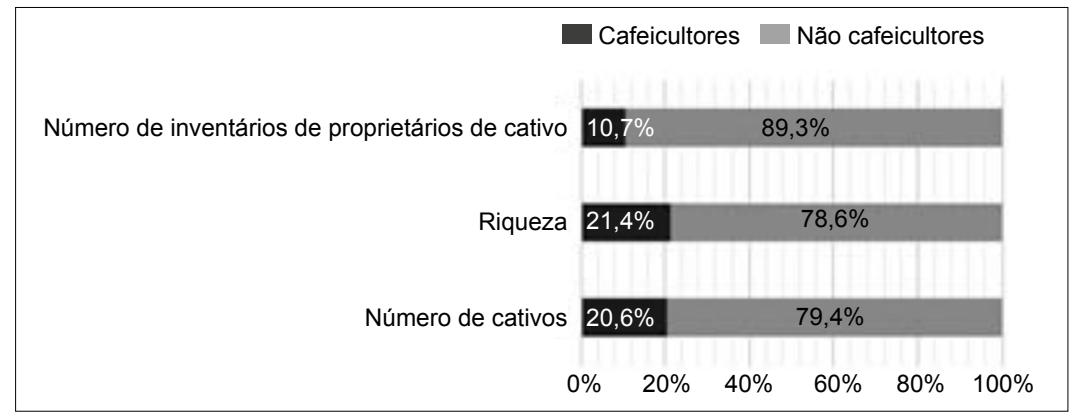

Fonte: Inventários post-mortem de Campanha (CEMEC e Fórum Municipal).

No que diz respeito à posse de escravos, como pode ser observado na Tabela 7, Campanha possuía relativamente poucos plantéis unitários,

12 O inventário do senhor Inácio José de Alvarenga destaca que em 1884 ele possuía, além de nove escravos, dos quais um era chapeleiro, uma casa onde funcionava a fábrica de chapéus. O documento não deixa claro, entretanto, se a fábrica ainda funcionava ou se havia sido fechada ou transferida de dono antes da morte de Inácio. Em 1888, constava nos bens de Francisco da Cunha Mendes uma fazenda de negócios no valor de $1: 913 \$ 119$, porém sem clareza de quais atividades eram exercidas ou qual o caráter desses negócios.

13 Considera-se riqueza o total de bens possuídos pelo indivíduo, isto é, o monte-mor. 
representando ainda menos em número absoluto de cativos se comparados a outras faixas de plantéis. Os pequenos, de dois a quatro escravos, eram os maiores, com 36\%, embora abarcassem apenas $13,7 \%$ do total de escravos. Os unitários e os pequenos compunham juntos a metade de todas as escravarias, mas detinham menos de um quarto do total dos cativos.

Tabela 7 - Estrutura da posse de cativos - Campanha, 1880-1888

\begin{tabular}{l|c|c|c|c|c|c}
\hline \multirow{2}{*}{ FTE $^{*}$} & \multicolumn{3}{c}{ SENHORES } & \multicolumn{3}{c}{ Escravos } \\
\cline { 2 - 7 } & \multicolumn{1}{c}{ Número } & \multicolumn{1}{c}{$\%$} & \multicolumn{1}{c}{$\%$ Acumulada } & \multicolumn{1}{c}{ Número } & \multicolumn{1}{c}{$\%$} & \% Acumulada \\
\hline 1 & 12 & 14,0 & 14,0 & 12 & 1,9 & 1,9 \\
\hline $2-4$ & 31 & 36,0 & 50,0 & 86 & 13,7 & 15,6 \\
\hline $5-9$ & 23 & 26,7 & 76,8 & 152 & 24,1 & 39,7 \\
\hline $10-29$ & 18 & 20,9 & 97,7 & 276 & 43,8 & 83,5 \\
\hline $30-49$ & 1 & 1,2 & 98,9 & 47 & 7,5 & 90,9 \\
\hline 50 e + & 1 & 1,2 & 100,0 & 57 & 9,0 & 100,0 \\
\hline Total & 86 & 100,0 & - & 630 & 100,0 & - \\
\hline
\end{tabular}

Fonte: Inventários post-mortem de Campanha (CEMEC e Fórum Municipal).

* Faixa de tamanho de escravaria.

A outra metade ficava por conta principalmente dos médios plantéis, de 5 a 9 e de 10 a 29 cativos, que juntos somavam mais de $47 \%$ das escravarias e detinham mais de dois terços da população escrava do município. A amostra apresenta apenas 2 grandes escravarias, que, embora representem pouco, $2,4 \%$, possuem mais de $16 \%$ da quantidade de cativos, ou seja, mais que os pequenos plantéis.

Tabela 8 - Estrutura da posse de cativos consoante atividade característica do inventário Campanha, 1880-1888

\begin{tabular}{|c|c|c|c|c|c|c|c|}
\hline \multirow[t]{2}{*}{ AtividAdes } & \multicolumn{6}{|c|}{ FTE $^{\star}$} & \multirow[t]{2}{*}{ TOTAL } \\
\hline & 1 & $2-4$ & $5-9$ & $10-29$ & $30-49$ & $50 \mathrm{e}+$ & \\
\hline Lavoura e/ou criação & 12 & 30 & 22 & 15 & 1 & 1 & 81 \\
\hline Negócio e criação & 1 & - & - & 1 & - & - & 2 \\
\hline Não identificada & - & 1 & 1 & 2 & - & - & 4 \\
\hline Total & 13 & 31 & 23 & 18 & 1 & 1 & 87 \\
\hline
\end{tabular}

Fonte: Inventários post-mortem de Campanha (CEMEC e Fórum Municipal).

* Faixa de tamanho de escravaria. 
De acordo com a Tabela 8 , todos os proprietários de cativos cuja atividade pôde ser identificada tem alguma relação com a terra, seja por meio da criação ou da lavoura. Em relação aos 2 negócios declarados nos processos, o primeiro, com 1 escravo, consistia em 1 farmácia em posse de Emiliana América Ximenes, que possuía ainda 10 animais, entre cavalos, muares e suínos. $\mathrm{O}$ segundo, com 20 cativos, tratava-se de 1 comércio de secos e molhados pertencente ao capitão Manoel Francisco Ribeiro, que detinha 22 animais, sendo 20 deles bovinos, 1 cavalo e 1 muar.

A partir da análise dos inventários, sabe-se que dona Emiliana possuía bens imóveis apenas urbanos, o que demonstra que seu escravo possivelmente era doméstico e os animais, para demanda própria.Já o capitão Manoel, no ano de 1888, possuía 37.000.000 em réis de imóveis rurais, enquanto 8.500 .000 em imóveis urbanos, o que evidencia possíveis atividades rurais. Seus escravos eram campeiros, cozinheiros, caseiros, roceiros e costureiras, além de 2 tropeiros, o que pode indicar que seu comércio cuidava ainda do transporte das mercadorias.

Dos proprietários que plantavam café, 4 apresentavam pequenas escravarias ( 2 a 4 cativos), 4 possuíam médias (10 a 29 cativos) e 1 detinha 47 escravos em 1 escravaria de grande porte. Nenhum cafeicultor aparenta possuir algum negócio. Desse modo, a década de 1880 foi ainda época de aproximação dos produtores com a rubiácea, que ainda desconfiavam do potencial que o dito ouro verde viria a ter nas décadas seguintes.

Ao contrário de Campanha, no mesmo período, a então Vila de Ribeirão Preto encontrava-se em pleno rush cafeeiro. Como foi visto, a valiosa rubiácea já estava presente desde meados da década de 1860 e, desde o início da década de 1870, o município se autodenominava "exclusivamente próprio para o plantio do café" ${ }^{14}$. A corrida por terras, que havia sido iniciada na década anterior, intensificou-se e o preço do alqueire de terras subiu significativamente. Segundo Jorge Henrique Caldeira de Oliveira, o valor médio do alqueire de terra negociado em

14 Em sessão de 22 de dezembro de 1874, os vereadores da cidade decidiram enviar algumas informações solicitadas pelo governo provincial "no sentido de demonstrar que este Município é exclusivamente próprio para o plantio do café. [...] Que existe alguns criadores de gado, porém que esses estão passando para o plantio do café" (Ata da Câmara Municipal, apud Santos, 1948, p. 84). 
Ribeirão Preto, em 1874, “chegou a 31\$037 [...] e somente 6 anos depois em 1880 já tinha aumentado mais de $100 \%$, chegando a $71 \$ 817$ " (Oliveira, 2003, p. 65).

Os trilhos da Companhia Mogiana, empresa fundada em Campinas, no ano de 1872 , alcançaram a cidade no ano de 1883 , facilitando o escoamento da produção e o trânsito de pessoas. Em 1888, o transporte de café, que em 1884 havia sido de 5.481,8 toneladas, já era de 8.467,3 toneladas.

Os inventários para o período 1880-1888 reúnem 98 documentos, dos quais $34(34,7 \%)$ registravam a presença de cativos. Desses 34 proprietários, $14(41,2 \%)$ eram do sexo feminino e 20 (58,8\%), do sexo masculino. Esses senhores e senhoras possuíam um total de 282 cativos, com posse média igual a 8,3 e desvio padrão de 10,3.

Os proprietários do sexo masculino detinham $55,7 \%$ dos cativos, com posse média igual a 7,6 e desvio-padrão de 10,7. O tamanho de posse mais comum era o unitário e o índice de Gini foi calculado em 0,570. Já as proprietárias concentravam 44,3\% dos cativos, com posse média igual a 8,9 e desvio-padrão de 10,2. O tamanho de posse mais comum também era o unitário.

Assim como em Campanha, a maior parte dos proprietários de cativos exercia atividades ligadas ao meio rural. Como pode ser observado no Gráfico 3, 85,3\% dos senhores eram lavradores e criadores, 2,9\% dedicavam-se aos negócios, 2,9\% eram profissionais liberais e 2,9\% dedicavam-se tanto aos negócios quanto às atividades rurais.

Gráfico 3 - Atividades dos proprietários de cativos - Ribeirão Preto, 1880-1888

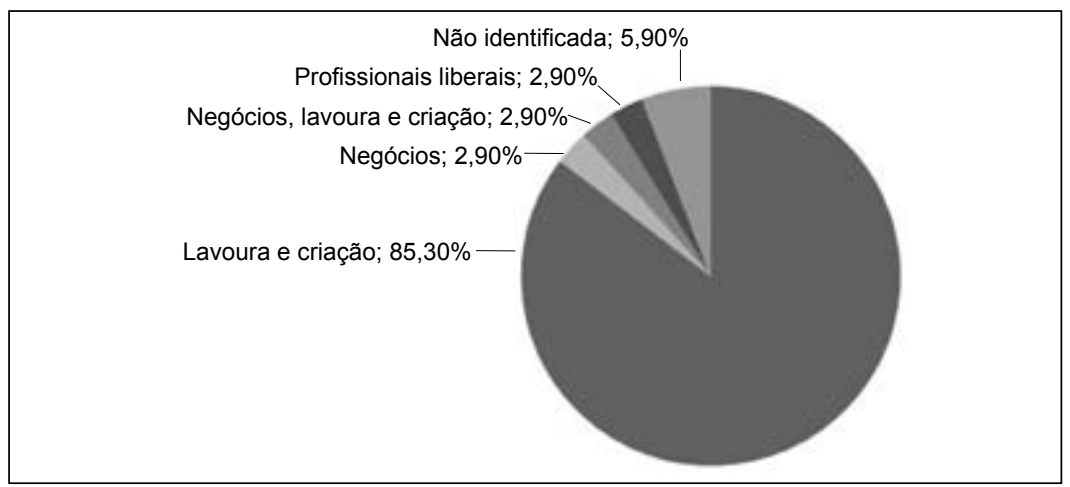

Fonte: Inventários post-mortem do Primeiro e Segundo Ofícios de Ribeirão Preto e São Simão. 
Os senhores que eram lavradores e/ou criadores cultivavam gêneros de subsistência, produtos de exportação, criavam gado e outros pequenos animais. Nos inventários foram encontradas plantações de milho, arroz, feijão, mandioca e cana-de-açúcar, além de criações de bovinos, suínos, ovinos e equinos. O café, principal produto de exportação cultivado na localidade, está presente em 14 processos, tanto como atividade principal como secundária. Esses cafeicultores, apesar de representarem menos da metade dos proprietários de cativos, detinham quase três quartos da riqueza inventariada e mais da metade da escravaria, como mostra o Gráfico 4.

Gráfico 4 - Participação dos cafeicultores nos inventários de proprietários de escravos Ribeirão Preto, 1880-1888

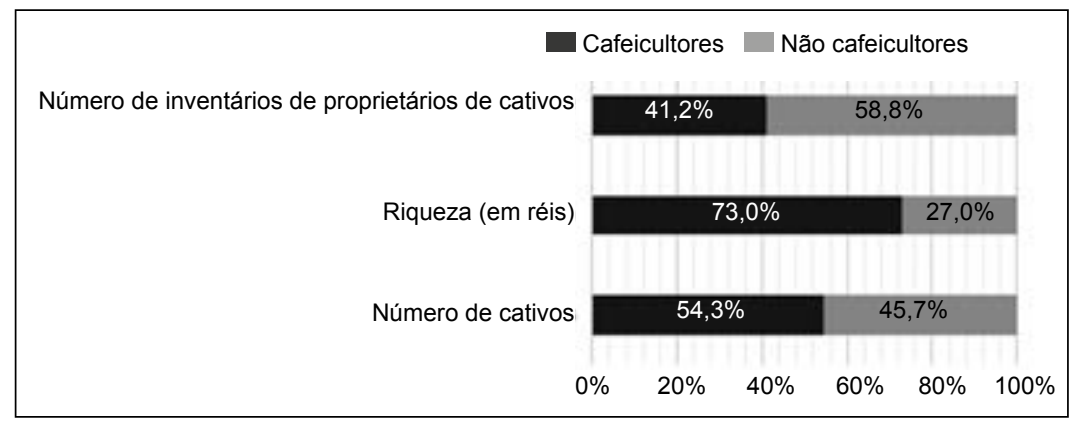

Fonte: Inventários post-mortem do Primeiro e Segundo Ofícios de Ribeirão Preto e São Simão.

Em Campanha, como foi visto anteriormente, a situação era distinta. Enquanto em Ribeirão Preto $42 \%$ dos proprietários de escravos eram cafeicultores, em Campanha essa porcentagem era de apenas 10,7\%. O mesmo pode ser dito com relação aos patrimônios. Em Ribeirão Preto, $73 \%$ do total dos patrimônios inventariados estava nas mãos de cafeicultores, enquanto em Campanha essa porcentagem era de 21,4\%. E por fim, em Ribeirão Preto, 54,3\% dos escravos inventariados pertenciam a cafeicultores, já em Campanha essa porcentagem era de tão somente $20,6 \%$. Ou seja, a participação relativa dos cafeicultores no cômputo geral de riqueza e propriedade escrava era muito mais relevante em Ribeirão Preto do que em Campanha, o que confirma os diferentes graus de desenvolvimento da lavoura cafeeira em ambas as cidades no momento considerado pelo presente estudo. 
Conforme os dados da Tabela 9, a maior parte dos plantéis são os unitários e pequenos, de 2 a 4 cativos. A porcentagem de plantéis unitários alcança 26,5\%. Os plantéis entre 2 e 4 cativos totalizam 23,5\%. Os plantéis médios, de 5 a 9 e de 10 a 29 cativos, somam 41,2\%. A porcentagem de grandes plantéis alcança $8,8 \%$.

Tabela 9 - Estrutura da posse de cativos - Ribeirão Preto, 1880-1888

\begin{tabular}{l|c|c|c|r|r|r}
\hline \multirow{2}{*}{ FTE $^{\star}$} & \multicolumn{3}{c}{ SENHORES } & \multicolumn{4}{c}{ Escravos } \\
\cline { 2 - 7 } & \multicolumn{1}{c}{ Número } & \multicolumn{1}{c}{$\%$} & \multicolumn{1}{c}{$\%$ Acumulada } & \multicolumn{1}{c}{ Número } & \multicolumn{1}{c}{$\%$} & \% Acumulada \\
\hline 1 & 9 & 26,5 & 26,5 & 9 & 3,2 & 3,2 \\
\hline $2-4$ & 8 & 23,5 & 50,0 & 25 & 8,9 & 12,1 \\
\hline $5-9$ & 9 & 26,5 & 76,5 & 56 & 19,9 & 32,0 \\
\hline $10-29$ & 5 & 14,7 & 91,2 & 85 & 30,1 & 62,1 \\
\hline $30-49$ & 3 & 8,8 & 100,0 & 107 & 37,9 & 100,0 \\
\hline 50 e + & - & - & - & - & - & - \\
\hline Total & 34 & 100,0 & - & 282 & 100,0 & - \\
\hline
\end{tabular}

Fonte: Inventários post-mortem do Primeiro e Segundo Ofícios de Ribeirão Preto e São Simão.

* Faixa de tamanho de escravaria.

Tabela 10 - Estrutura da posse de cativos consoante atividade/ocupação do inventariado Ribeirão Preto, 1880-1888

\begin{tabular}{|c|c|c|c|c|c|c|c|}
\hline \multirow[t]{2}{*}{ AtividADES } & \multicolumn{6}{|c|}{$\mathrm{FTE}^{\star}$} & \multirow[t]{2}{*}{ TOTAL } \\
\hline & 1 & $2-4$ & $5-9$ & $10-29$ & $30-49$ & $50 \mathrm{e}+$ & \\
\hline Lavoura e/ou criação & 8 & 7 & 7 & 4 & 3 & - & 29 \\
\hline Negócio & - & - & 1 & - & - & - & 1 \\
\hline Negócio, lavoura e criação & - & 1 & - & - & - & - & 1 \\
\hline Profissionais liberais & 1 & - & - & - & - & - & 1 \\
\hline Não identificada & - & - & 1 & 1 & - & - & 2 \\
\hline Total & 9 & 8 & 9 & 5 & 3 & 0 & 34 \\
\hline
\end{tabular}

Fonte: Inventários post-mortem do Primeiro e Segundo Ofícios de Ribeirão Preto e São Simão.

$\star$ Faixa de tamanho de escravaria.

A análise dos dados apresentados na Tabela 10 mostra que não foi possível identificar uma relação direta entre atividade do inventário e tamanho de posse de cativos. As médias e grandes posses nem sempre estavam empregadas em atividades exclusivamente rurais, do mesmo modo havia proprietários com ocupações de caráter mais urbano que possuíam plantéis de médio porte. Esse é o caso do negociante Francisco Custódio Braga. Sua esposa, Maria Victoria de Jesus, faleceu 
em Ribeirão Preto, no ano de 1883. No inventário dos bens do casal, constava uma casa na vila, um casal de bovinos, algumas dívidas passivas e os escravos: Joana, 20 anos; Jacintha, 19 anos; Mariana, 14 anos; Casimiro, 27 anos, libertado no testamento; e Maria, 49 anos, também libertada no testamento. Ao que tudo indica, Francisco possuía o negócio em sociedade com dois irmãos, listados na "Qualificação de votantes" como caixeiros.

Além de analisar a estrutura da posse de todos os proprietários, torna-se relevante percorrer a estrutura da posse dos que cultivavam café. Ainda que esses senhores não possam ser comparados com os grandes cafeicultores que a localidade abrigou durante o final do século XIX e início do século XX, o estudo de sua estrutura de posse, assim como das características de sua escravaria, podem ajudar a compreender os momentos iniciais da cafeicultura no novo oeste de São Paulo.

Conforme os dados da Tabela 11, os proprietários de cativos que cultivavam café possuíam plantéis de quase todas as faixas de tamanho consideradas. A maior parte destes tinha escravarias entre dois e nove elementos com razões de sexo elevadas. Considerando a totalidade dos cativos, a razão de sexo foi calculada em 129,3. Considerando apenas os cativos dos cafeicultores, esse índice sobe para 142,9.

A proporção de homens na população cativa ribeirão-pretana, ainda que elevada, não chegava a ser tão grande quanto a encontrada para outras localidades com economias voltadas à grande lavoura de exportação, em especial o café. Warren Dean, estudando a economia de Rio Claro, encontrou para os anos de 1884 e 1887 razões de sexo iguais a 158,4 e 164,3 respectivamente (cf. Dean, 1977, p. 71). Analisando as alforrias em Campinas, Peter Eisenberg encontrou razões de sexo ainda maiores. Para o ano de 1885, esse índice foi calculado em 196,9, e para o período 1886-1887 o mesmo indicador chegou a 213,3 (cf. Eisenberg, 1987 , p. 185). Ao estudar a propriedade cativa na antiga Vila de Mogi-Mirim no período 1851-1888 utilizando as informações dos inventários post-mortem da localidade, Leonel de Oliveira Soares também encontrou razões de sexo elevadas, em especial dos cativos cujos proprietários eram produtores de derivados de cana ou café. A razão de sexo dos escravos cujos senhores eram produtores de cana-de-açúcar e derivados foi calculada em 182,2. O cálculo do mesmo índice para os cafeicultores resultou em 157,4. E, finalmente, os cativos daqueles que produziam 
derivados de cana-de-açúcar e também café tinham razão de sexo igual a 181,4 (cf. Soares, 2003, p. 105).

Tabela 11 - Estrutura da posse de escravos dos cafeicultores - Ribeirão Preto, 1880-1888

\begin{tabular}{l|c|c|c|c|c|c|c|c}
\hline \multirow{2}{*}{ Atividades } & \multicolumn{7}{c}{ FTE $^{\star}$} & \multicolumn{1}{c}{ Total } \\
\cline { 2 - 9 } & 1 & $2-4$ & $5-9$ & $10-29$ & $30-49$ & $50 \mathrm{e}+$ & \\
\hline Lavoura e/ou criação & 2 & 3 & 4 & 2 & 2 & - & 13 \\
\hline Negócio, lavoura e criação & - & 1 & - & - & - & - & 1 \\
\hline Total & 2 & 4 & 4 & 2 & 2 & 0 & 14 \\
\hline
\end{tabular}

Fonte: Inventários post-mortem do Primeiro e Segundo Ofícios de Ribeirão Preto e São Simão.

$\star$ Faixa de tamanho de escravaria.

Um desses cafeicultores era José Dias de Oliveira. Quando faleceu, José era casado com Marcolina Francisca do Nascimento, com quem tinha nove filhos. Entre seus bens foram encontrados alguns móveis, terras na Fazenda Boa Vista com algumas benfeitorias, 80 alqueires de café com casca, além dos cativos: Iria, 13 anos; Pedro, 15 anos; Joaquim, 23 anos; Gabriel, 25 anos; João, 33 anos; e Ignez, com 43 anos. O cafezal possuído por Oliveira não estava localizado em terras de sua propriedade. Tal ocorrência não era comum, já que normalmente os cafezais encontrados eram plantados em terras do próprio inventariado. Além da mão de obra dos cativos e possivelmente de sua família, José contava também com a ajuda de um agregado, Francisco Cunha.

\section{Considerações finais}

O presente artigo apresenta os primeiros resultados de uma reflexão ainda em andamento. Por essa razão, mais importante nesse momento do que encontrar ou analisar as razões que fizeram com que tantos sul-mineiros se dirigissem para o nordeste paulista ao longo dos Oitocentos, é o entendimento das particularidades de cada uma das localidades estudadas.

Nesse sentido, os dados apresentados mostraram que a posse cativa em Campanha e Ribeirão Preto não se mostrou muito distante dos padrões tradicionais presentes na historiografia. Para ambas as localidades, encontrou-se uma quantidade maior de pequenas escravarias, embora 
as faixas médias de tamanho de posse concentrassem maior número de cativos. As principais atividades dos proprietários de cativos eram a lavoura e a criação de animais, com destaque para os inventários em que foi localizada a cultura cafeeira. Em Campanha, os processos com lavoura de café empregavam quase metade dos escravos em escravarias pequenas, de 2 a 4 cativos, e quase a outra metade em escravarias médias, de 10 a 29; 1 posse apresentava 47 elementos. Já, em Ribeirão Preto, a valiosa rubiácea estava presente em inventários de proprietários com escravarias dos mais diversos tamanhos, desde as posses unitárias até os plantéis com mais de 30 cativos.

Depreende-se que, apesar de ser uma localidade de constituição mais recente, Ribeirão Preto experimentou um rápido desenvolvimento da cafeicultura, afirmação que é corroborada pela maior participação dos cafeicultores no cômputo geral da riqueza e dos escravos inventariados.

Espera-se que tais reflexões amadureçam, talvez dando origem a novos trabalhos comparativos não só entre as duas cidades escolhidas, mas também entre as duas regiões às quais estas são pertencentes, o Sul de Minas e o nordeste paulista.

\section{Fontes}

\section{Fontes primárias manuscritas}

INVENTÁRIOS post-mortem de Campanha.

INVENTÁRIOS post-mortem do Primeiro e Segundo Ofícios de Ribeirão Preto e São Simão.

\section{Fontes primárias impressas}

D’ALINCOURT, Luiz. Memória sobre a viagem do Porto de Santos à cidade de Cuiabá. São Paulo: Itatiaia/EDUSP, 1975.

LAEMMERT, Eduardo von. Almanak das Provincias do Imperio do Brazil para 1885. Organizado e redigido por Arthur Sauer. Rio de Janeiro: Casa dos Editores Proprietarios Laemmert \& C., 1885.

LUNÉ,A. José B.; FONSECA, Paulo D. da. Almanak da Provincia de São Paulo. São Paulo, 1873.

MÜLLER, Daniel Pedro. Ensaio d'um quadro estatístico da Província de São Paulo: ordenado pelas leis municipais de 11 de julho de 1836 e 10 de março de 1837. 3. ed. fac. São Paulo: Governo do Estado, 1978. 
VEIGA, Bernardo Saturnino da. Almanach Sul-Mineiro. Campanha: Typographia do Monitor Sul-Mineiro, 1874.

\section{Referências bibliográficas}

ABREU, Alzira Alves de. Dicionário histórico-biográfico da Primeira República (1889-1930). Rio de Janeiro: Fundação Getúlio Vargas, 2015, versão eletrônica.

ALCÂNTARA MACHADO, José de. Vida e morte do bandeirante. São Paulo/Brasília: Martins/INL, 1972.

ANDRADE, Marcos Ferreira de. Elite escravista no Sul de Minas Gerais: opções de investimento e composição da riqueza - século XIX. XIV SEMINÁRIO SOBRE ECONOMIA MINEIRA, 2010, Diamantina. Trabalho completo: ANAIS ELETRÔNICOS DO XIV SEMINÁRIO SOBRE ECONOMIA MINEIRA.V. 1. Belo Horizonte: CEDEPLAR-UFMG, 2010, p. 1-19.

ANDRADE, Marcos Ferreira de; CARDOSO, Maria Tereza Pereira. A Vila da Campanha da Princesa: fontes para a história do Sul de Minas. Varia Historia. Belo Horizonte, v. 23, p. 214-233, 2000.

BASSANEZI, Maria Silvia C. (org.). São Paulo do passado. V. I. Campinas: NEPO-UNICAMP, 1998 (1836).

CASTILHO, Fábio Francisco de Almeida. Economia sul-mineira: o abastecimento interno e a expansão cafeeira (1870-1920). Revista de História Econômica E Economia Regional Aplicada. Juiz de Fora, v. 4, n. 1, 2009.

COSTA, Maria Lucia Prado. Fontes para a história social do Sul de Minas: os trabalhadores de Paraguaçu e Machado (1850-1900). Belo Horizonte: Mazza, 2002.

CUSTÓDIO SOBRINHO, Juliano. Escravos, polícia e conflitos sociais às vésperas da abolição. Minas Gerais - 1880-1888. XXVI SIMPÓSIO NACIONAL DE HISTÓRIA, 2011, São Paulo. Trabalho completo: ANAIS DO XXVI SIMPÓSIO NACIONAL DE HISTÓRIA. São Paulo: ANPUH, 2011.

DEAN, Warren. Rio Claro: um sistema brasileiro de grande lavoura, 1820-1920. Trad. Waldívia Portinho. Rio de Janeiro: Paz e Terra, 1977.

EISENBERG, Peter L. Ficando livre: as alforrias em Campinas no século XIX. Estudos Econômicos, 17 (2), p. 175-216, maio-ago. 1987.

FILETTO, Ferdinando; ALENCAR, Edgar. Introdução e expansão do café na região Sul de Minas Gerais. Revista de Administração da UFLA. Lavras, v. 3, n. 1, 2001.

FLEXOR, Maria Helena O. Inventários e testamentos como fontes de pesquisa. Campinas, [1986-2006]. Disponível em <http://www.histedbr.fe.unicamp.br/navegando/ artigos_frames/artigo_074.html>.Acesso em out. 2018.

GIROLETTI, Domingos. A industrialização de Juiz de Fora. Belo Horizonte: Fundação João Pinheiro, 1980.

GRAÇA FILHO,Afonso Alencastro. A Princesa do Oeste: elite mercantil e economia de subsistência em São João del-Rei (1831-1888). São Paulo: Annablume, 2002. 
IBGE - INSTITUTO BRASILEIRO DE GEOGRAFIA E ESTATÍSTICA. Campanha, Minas Gerais-MG. Enciclopédia dos municípios brasileiros.V. XXIV, 1958. Disponível em < http://biblioteca.ibge.gov.br/visualizacao/dtbs/minasgerais/campanha. pdf>. Acesso em nov. 2014.

LAGES, J. A. Ribeirão Preto: da Figueira à Barra do Retiro. Ribeirão Preto:VGA, 1996.

LANNA, Ana. A transformação do trabalho: a passagem para o trabalho livre na Zona da Mata Mineira, 1870-1920. Campinas: Editora da UNICAMP, 1988.

LENHARO, Alcir. As tropas da moderação: o abastecimento da corte na formação da política do Brasil, 1808-1842. 2. ed. Rio de Janeiro: Departamento Geral de Documentação e Informação Cultural, Secretaria Municipal de Cultura, Turismo e Esportes, Divisão de Editoração, 1993.

LIMA, João Heraldo. Café e indústria em Minas Gerais, 1870-1920. Rio de Janeiro:Vozes, 1981.

MARCONDES, Renato Leite. A propriedade escrava no Vale do Paraíba Paulista durante a década de 1870. São Paulo: FEA-USP - Ribeirão Preto, 2000, mimeo. (Texto para Discussão, Série Economia, 10).

MARCONDES, Renato Leite. O café em Ribeirão Preto. Ribeirão Preto: FEARP, 2002 (Texto para Discussão, Série Economia, 30).

MIRANDA, J. P. de. Ribeirão Preto de ontem e de hoje. Ribeirão Preto: El Dorado, 1971.

MOTTA, J. F.; MARCONDES, R. L. O comércio de escravos noVale do Paraíba paulista: Guaratinguetá e Silveiras na década de 1870. Estudos Econômicos. São Paulo, v. 30, n. 2, p. 267-299, 2000.

OLIVEIRA, Lélio Luiz de. Ao lado do café: produção de exportação e de abastecimento em Franca. São Paulo: Departamento de História Econômica, Faculdade de Filosofia, Letras e Ciências Humanas, Universidade de São Paulo, 2003, mimeo. (Tese de Doutorado).

PENHA, Lauriano José Martins. Carta do Império do Brasil com a designação das ferrovias, colônias, engenhos centrais, linhas telegráficas e de navegação a vapor. Rio de Janeiro: Lith. Paulo Robin, \& Ca., 1883.

PIRES, Anderson. Capital agrário, investimento e crise na cafeicultura de Juiz de Fora (18701930). Niterói: UFF, 1993 (Dissertação de Mestrado).

REBELLO, Ricardo Moreira. O município de Machado até a virada do milênio. Machado: s.ed., 2006.

SAES, Alexandre Macchione; CASTILHO, Fábio Francisco de Almeida. Cortando a Mantiqueira: entre café e abastecimento no Sul de Minas (1880-1920). Saeculum

- Revista de História. João Pessoa, n. 29, 2013.

SAINT-HILAIRE, A. d. Viagem à Província de São Paulo. São Paulo: Itatiaia, 1976.

SANTOS, Plínio Travassos dos. Ribeirão Preto: histórico e para a história. Ribeirão Preto, 1948, mimeo.

SOARES, Leonel de Oliveira. No caminho dos Goiases: formação e desenvolvimento da economia escravista na Mogi-Mirim do século XIX. São Paulo: Departamento de História Social, Faculdade de Filosofia, Letras e Ciências Humanas, Universidade de São Paulo, 2003, mimeo. (Dissertação de Mestrado). 
SOARES, Moacyr Brêtas. Muzambinho: sua história e seus homens. S.1.: s.ed., 1940.

TAUNAY, A. d'Escragnolle. História do café no Brasil.V. 2, 3. Rio de Janeiro: Departamento Nacional do Café, 1939.

VALVERDE, Orlando. A fazenda de café escravocrata no Brasil. Revista Brasileira de Geografia, v. 29, n. 1, 1967.

VITTORETTO, Bruno Novelino. A conformação da Zona da Mata mineira no mercado mundial do café do século XIX. Revista de História Econômica e Economia Regional Aplicada. Juiz de Fora, UFJF, v. 5, n. 9, jul.-dez. 2010.

ZEMELLA, Mafalda P. O abastecimento da Capitania de Minas Gerais no século XVIII. São Paulo: HUCITEC/EDUSP, 1990. 